\title{
Honoré de Balzac, Piccole Miserie della vita coniugale
}

\section{Marco Stupazzoni}

\section{Q OpenEdition}

\section{Journals}

\section{Edizione digitale}

URL: https://journals.openedition.org/studifrancesi/3139

DOI: 10.4000/studifrancesi.3139

ISSN: 2421-5856

\section{Editore}

Rosenberg \& Sellier

\section{Edizione cartacea}

Data di pubblicazione: 1 juillet 2013

Paginazione: 470

ISSN: 0039-2944

\section{Notizia bibliografica digitale}

Marco Stupazzoni, «Honoré de Balzac, Piccole Miserie della vita coniugale», Studi Francesi [Online], 170 (LVII | II) | 2013, online dal 30 novembre 2015, consultato il 02 février 2023. URL: http:// journals.openedition.org/studifrancesi/3139; DOI: https://doi.org/10.4000/studifrancesi.3139

Questo documento è stato generato automaticamente il 2 février 2023.

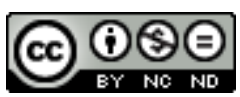

Creative Commons - Attribuzione - Non commerciale - Non opere derivate 4.0 Internazionale - CC BYNC-ND 4.0

https://creativecommons.org/licenses/by-nc-nd/4.0/ 


\title{
Honoré de Balzac, Piccole Miserie della vita coniugale
}

\author{
Marco Stupazzoni
}

\section{NOTIZIA}

HONORÉ DE BALZAC, Piccole Miserie della vita coniugale, introduzione di Daniele ANSELMO, Palermo, Torri del Vento Edizioni, 2011, «I Capperi», pp. 270.

1 Tra le opere di maggior successo nel panorama editoriale italiano dall'Ottocento ad oggi, v'è, senza alcun dubbio, e insieme alla Physiologie du mariage, il testo delle Petites Misères de la vie conjugale. Pubblicato in prima edizione nel luglio del 1845 presso l'editore Chlendowski (con illustrazioni di Bertall), lo scritto balzachiano sarà arricchito e completato con nuovi capitoli nell'edizione del luglio 1846.

2 Daniele Anselmo (a cui si deve con tutta probabilità anche la traduzione dell'opera) sottolinea, nella Prefazione che introduce questa nuova traduzione italiana dello scritto di Balzac, l'attualità delle parole dello scrittore francese a discapito dell'evoluzione storico-sociale, culturale e scientifica dell'uomo nel corso dei secoli. Petites Misères de la vie conjugale, osserva il curatore, sembra «una storia destinata a ripetersi all'infinito, un eterno ritorno dal quale non vi è una via d'uscita» (p. 6). 